\title{
The disaster response performance of hospitals in Taiwan: evaluation and classification
}

\author{
Fuh-Hwa Franklin Liu • Ying-Hock Teng • \\ Ching-Hsiang Lai
}

Published online: 7 April 2010

(C) Springer Science+Business Media B.V. 2010

\begin{abstract}
Hospitals need disaster response plannings and temporary shelters to rescue victims in disasters. In Taiwan, there are 82 emergency medical service (EMS) hospitals are requested to possess guildlines of preparedness and responses to mitigation the damage and recovery the pre-event status in a disaster. A measurement chart including three major factors - facility, manpower, and disaster plan and drill mode-was created to evaluate the performance of disaster management of these EMS hospitals. Based on the expert opinions, some hospitals were selected as a reference set prior to the accreditation. Data envelopment analysis (DEA) is applied to classify each of the remaining hospitals into qualified or unqualified classes. Then, each unqualified hospital was recommended to improve its practice of disaster preparedness and responses into the qualified level. We also find that, on average, private hospitals perform better than public hospitals and medical centers perform better than the regional hospitals. But, the differences are not statistically significant.
\end{abstract}

Keywords Disaster response planning · Data envelopment analysis (DEA) · Performance $\cdot$ Classification · Emergency medical service (EMS)

F.-H. F. Liu

Department of Industrial Engineering and Management, National Chiao Tung University, 1001, University Road, Hsinchu 300, Taiwan

Y.-H. Teng

Department of Emergency Medicine, Chung Shan Medical University Hospital, 110, Sec. 1, Jianguo North Road, Taichung 402, Taiwan

C.-H. Lai $(\bowtie)$

School of Applied Information Sciences, Chung Shan Medical University, 110, Sec. 1, Jianguo North Road, Taichung, 402, Taiwan

e-mail: liay@csmu.edu.tw 


\section{Background of motivation}

Man-made and natural disasters often occur around the world. Taiwan suffered a major earthquake in the early morning on 21 September 1999 . More than 2,400 people died and 8,000 people sustained injuries in the fault areas. Hospitals located near the fault received mass casualties after the quake. Most of the victims arrived at an emergency department (ED) in the initial hours (Chen et al. 2001). Although many health care providers and medical resources were sent into the disaster area, the hospitals were severely damaged, and some of them even had function loss. Based on the emergency medical service (EMS) level, when hospitals were damaged beyond operating facility, patients needed to be transferred because of the lack of temporary shelters or field hospitals.

The American Red Cross often coordinates and staffs mass shelters to care for people who have physical or mental limitations that restrict their mobility or ability to function independently. These individuals may require assistance with daily life activities, or medication to sustain them. Long road journeys may be harmful to their health. Because these individuals are often at the highest risk, human and economic resources should be allocated to enhance their survival and promote their well being during a catastrophe. Pretto et al. $(1992,1994)$ demonstrated that there were many victims whose deaths might have been prevented if they had received medical attention in the first $6 \mathrm{~h}$ after the tremor. Safar (1986) showed that about $25-50 \%$ of the patients could have been saved if emergency care had been rendered at once. Therefore, it is imperative for a medical response system to be maximally efficient so that medical care can be administered as soon as possible to reduce mortality rates.

The Joint Commission on Accreditation of Healthcare Organizations (JCAHO) requires that hospitals have emergency plans "designed to manage the consequences of natural disasters or other emergencies that disrupt the hospital's ability to provide care and treatment" (JCAHO 1994). The plans must be specific in the hospital's role in community-wide emergency preparedness, the procedures of implementation, the management of key materials and activities, staff deployment and roles, the management of patient care services, staff preparation, disaster drills, and monitoring and evaluation of hospital performance.

A successful, comprehensive, and risk-based emergency management program of disaster preparedness, response, and recovery will reduce the loss of life and resources. A standard requires detailed written plans for all potential emergencies and disasters in the facility or community, training for all employees as soon as they begin work at the facility, periodic reviews of procedures with staff, and unannounced drills.

There are several such instruments of national or regional importance in the world. For instance, in Europe, the Sphere Project, a consortium of non-governmental organizations, has formulated a "Humanitarian Charter and Minimum Standards in Disaster Response" (Sphere Project 2004). It is the first general standard for humanitarian operations, and a distillation of great experience and worldwide consultation. In the USA, the National Fire Protection Association (NFPA) has prepared a "Standard on Disaster/Emergency Management and Business Continuity Programs" (NFPA 2007). In Australia, the Australian Standards Organization has an "Australia/New Zealand Risk Management Standard" (The Joint Australian/New Zealand Standard 2004). This instrument uses a standardized and widely accepted risk management methodology, and is thus an important and authoritative source of support for risk management policies. In Taiwan, the law regarding emergency medical care was legislated in 1995 and revised in 2000, 2002, 2005, and 2007 (Department of Health 2007), and the rule pertaining to disaster protection was implemented in 2000 (Department of Health 2000). There are provisions about disaster protection and care for large numbers of patients. 
Disaster scholar Aghababian et al. (1994) indicated that a hospital should plan to take care of inner and outer disasters in advance. The hospital is required to consider manpower and equipment deficiency in disaster. The problem of manpower refers to the lack of the medical staff required to take care of a massive number of patients. The equipment includes the supply of electricity (power), water, oxygen, and so on. Besides these, the EMS hospitals should plan for a temporary shelter to confront major disasters. The book, "Community Medical Planning and Evaluation Guide" (Heide 1995), published by America College Emergency Physician (ACEP), provides a detailed form to evaluate the building, telephone, radio, records, and computer information, and is a very good reference for disaster preparation and recovery.

In Taiwan, hospital accreditation was initiated in 1986. The purpose of accreditation was to promote the quality of medical care. In 2000, 16 public (government) and non-profit hospitals were accredited as teaching medical centers, and 88 moderate-sized hospitals were accredited as regional teaching hospitals. During a field visit, the evaluation of EDs was performed in isolation by authorized emergency physicians. Also, evaluation was used to increase the quality of emergency services. However, it did not include emergency evacuation and temporary shelters as a part of the evaluation issue. To improve the performance and quality of disaster emergency care of Taiwan's EMS hospitals, we established an evaluation program that focuses on disaster preparedness planning and temporary shelters. This research is a pioneer study in the field of EMS and disaster preparedness in Taiwan.

\section{Accreditation of disaster preparedness and temporary shelters}

In Taiwan, hospital accreditation is usually based on a measurement chart which is created by an evaluation committee convened by the Department of Health (DOH). We performed the accreditation of disaster preparedness planning and temporary shelters in EMS hospitals in 2001. A measurement chart and evaluation guide were created by the disaster planning evaluation committee. The chart was based on the "Community Medical Planning and Evaluation Guide" (Heide 1995), consulted the "Hospital Accreditation and Evaluation Table" of DOH (Taiwan Joint Commission on Hospital Accreditation 1999), and modified through discussion among the members of the committee and some experts in the fields of health, fire and construction in a conference. The final version of the measurement chart and evaluation guide is listed in the appendix.

The chart includes three major factors: facility, manpower, and disaster plan and drill mode. Each factor consists of some related items, and each item was assigned a different point in accordance with its different consequences. The total points for each factor is the sum of the points of items included in it. For instance, the facility factor includes the following 18 items: space ownership, space type, space area, space site, space capacity, space design, power supply, ventilation facilities, water supply, communication facilities, oxygen supply, transportation, emergency equipment, eating space, dressing and sleeping supply, toilet, bathroom, and kitchen. The points assigned to space design is 7, while for transportation it is 3 . The total points of facility, 65, is the sum of the points of the above 18 items. Similarly, the total points of manpower, and disaster plan and drill mode are 20 and 15, respectively.

For each item, the accredited ranks are divided into five levels: excellent, good, adequate, mild deficiency, and deficiency, each with corresponding weights, 1, 0.8, 0.6, 0.4, and 0.2, respectively. If a hospital was accredited as at a good level in the space design item, the point score gained in this item was 5.6, which equals the item point, 7, multiplied by the rank weight, 0.8. In this chart, the accredited points of all items were designed higher as the hospital performed better in the accreditation. 
The accreditation process was performed from December 2000 to December 2001. After deleting non-teaching hospitals and teaching hospitals without EMS, we interviewed 82 hospitals, among which $16(19.5 \%)$ were medical centers and 66 (80.5\%) were regional hospitals. The three accredited points of the hospitals are listed in Table 1, in the increasing order of their monthly emergency patients. Our study is based on the following two assumptions: (i) In the disaster area, if a hospital ordinarily receives more emergency visits, then it will receive relatively more patients if a disaster occurs, and (ii) A good quality of preparedness plan will rescue more victims in a disaster.

Thus, the 82 hospitals were partitioned into two groups according to the monthly emergency patients: the hospitals with minor EMS as a reference set, and the hospitals with major EMS to be accredited, denoted as $\boldsymbol{R}$ and $\boldsymbol{A}$, respectively. The committee should choose a specific percentage of hospitals on the top of Table 1 as $\boldsymbol{R}$ and the rest as $\boldsymbol{A}$. To illustrate our methodology, we set the specific percentage at about 10\%, and groups $\boldsymbol{R}$ and $\boldsymbol{A}$ have 9 and 73 hospitals, respectively. It is reasonable to expect that the hospitals in $\boldsymbol{A}$ will perform better than those in $\boldsymbol{R}$ in terms of disaster preparedness. However, a hospital in $\boldsymbol{A}$ is accredited as "qualified" if it outperformed all members of group $\boldsymbol{R}$, otherwise it is "unqualified".

We employed data envelopment analysis (DEA) model (Seiford and Zhu 1998) to assess the performance of each hospital with respects to $\boldsymbol{R}$. Its optimal value is used to classify hospitals in $\boldsymbol{A}$ into the qualified or unqualified class. It also provides the direction and extent of improvement for the unqualified hospitals. The DEA models for the performance assessment are introduced in the Sect. 3. The results are presented in Sect. 4. Conclusions and discussions are presented in Sect. 5 .

\section{Methodology}

Many researchers have used DEA methods to examine differences in health care system performance. Burgess and Wilson (1996) used it to analyze the differences of four types of ownership structure in the hospital industry in the USA - private non-profit, private for-profit, federal, and state and local government. They also used DEA efficiency scores as regressive variable for exogenous variables to gain insight into various issues impacting the debate over health-care reform in USA (Burgess and Wilson 1998). Hofmarcher et al. (2002) investigated the evolution of efficiency and productivity in the hospital sector of an Austrian province from 1994 to 1996. Grosskopf et al. (2001) used a frontiers approach to compare the teaching and non-teaching hospitals under their best practice performance.

Data envelopment analysis (DEA), originally proposed by Charnes et al. (1978), is a multiple input-output efficient technique that measures the relative performances of decision-making units (DMUs) using linear programming based models. It is non-parametric because it requires no assumption on the weights of the underlying production function. In this paper, let $H_{j}$ denote hospital $j$ and the symbols $y_{1 j}, y_{2 j}$, and $y_{3 j}$ denote the points of facility, manpower, and disaster plan and drill mode corresponding to $H_{j}$, respectively. The relative performance of a specific hospital $k$ is obtained by the following DEA model:

$$
\begin{array}{ll}
t_{k}^{*}=\max & \sum_{r=1}^{3} u_{r} y_{r k} \\
\text { s.t. } & \sum_{r=1}^{3} u_{r} y_{r j} \leq 1, \quad j \in \boldsymbol{R} \\
& u_{r} \geq 0, \quad r=1,2,3 .
\end{array}
$$




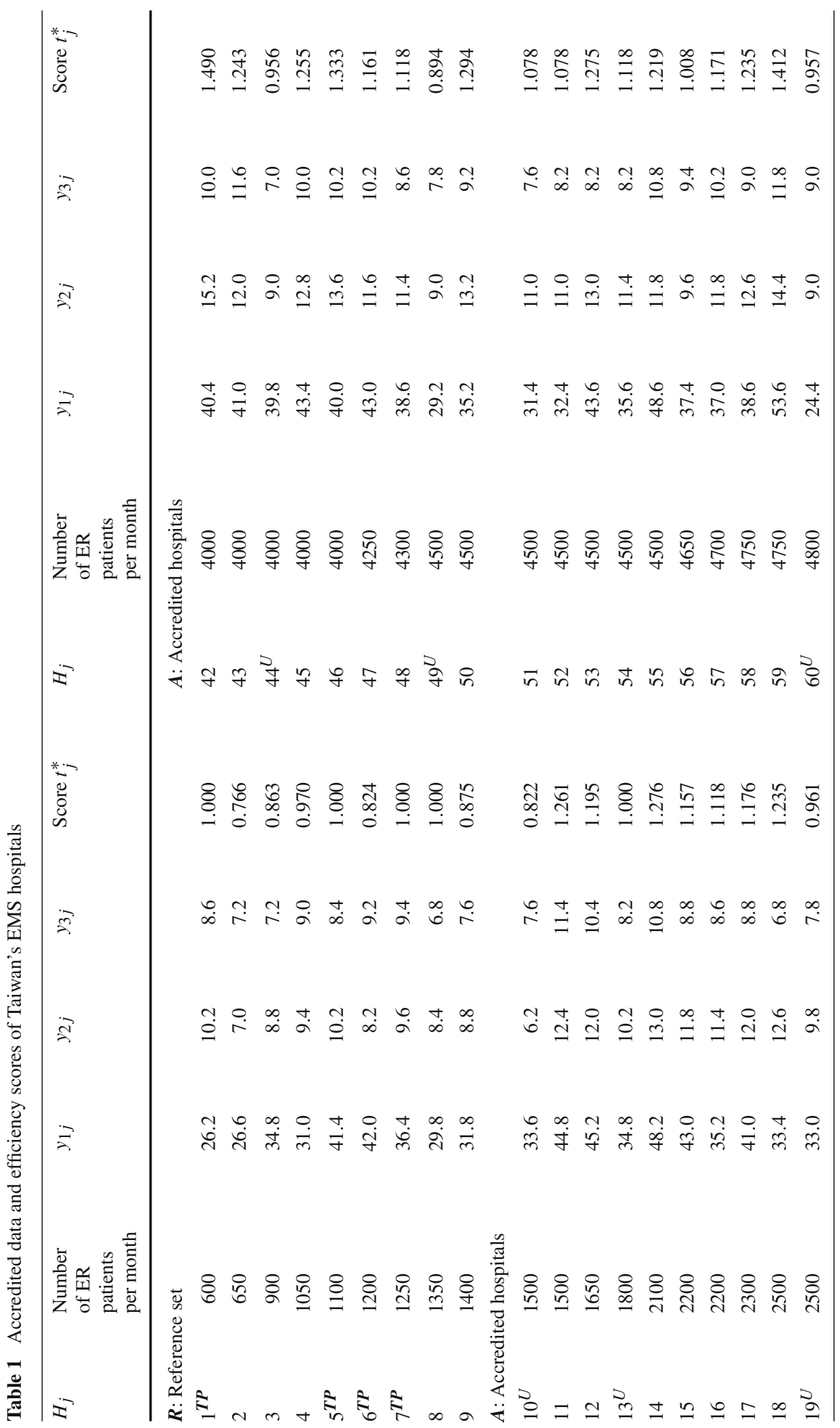




\begin{tabular}{|c|c|}
\hline 管 & 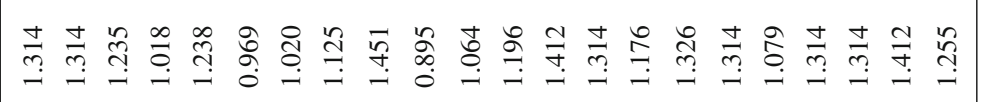 \\
\hline$\grave{\curvearrowright}$ & 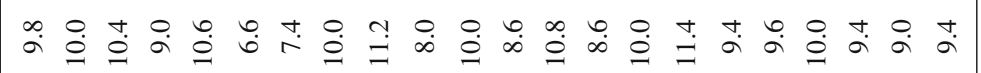 \\
\hline$\vec{\Im}$ & 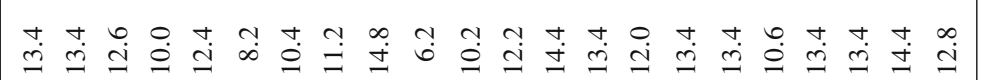 \\
\hline$\Xi$ & 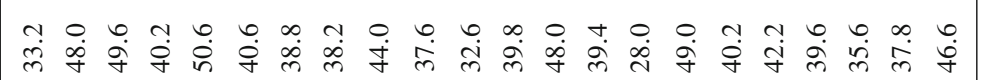 \\
\hline 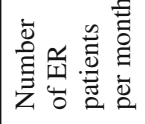 & 宓 \& \\
\hline $\bar{I}$ & 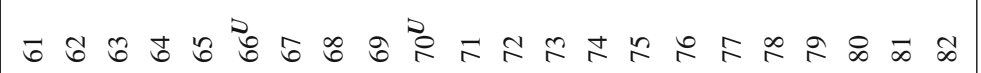 \\
\hline$\stackrel{\text { *- }}{*}$ & 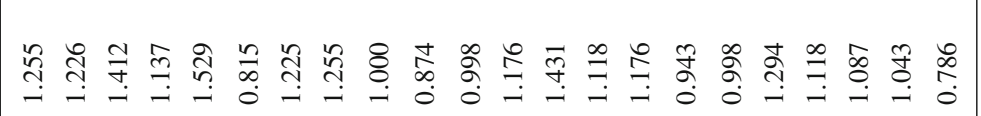 \\
\hline 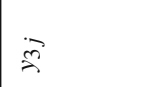 & 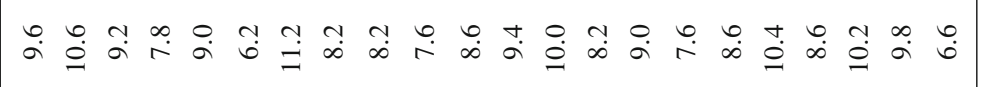 \\
\hline 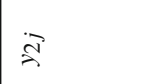 & 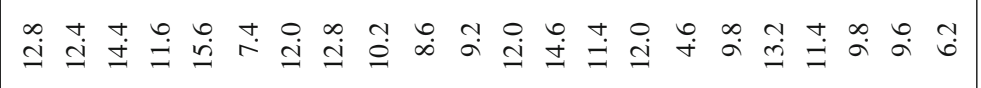 \\
\hline 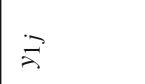 & 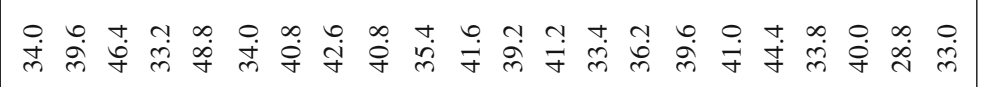 \\
\hline 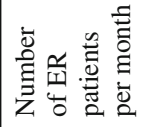 & \& \\
\hline $\bar{\Sigma}$ & 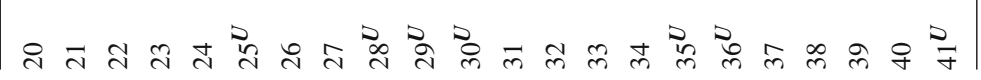 \\
\hline
\end{tabular}


The decision variable $u_{r}$ is the weight assigned to factor $r$. The relative performance, $t_{k}^{*}$, is evaluated without predetermining weights of these factors. The weights are settled by maximizing the performance of $H_{k}$ and restricting all hospitals in $\boldsymbol{R}$ with performance not greater than one.

In the event of a hospital $k$ belonging to $\boldsymbol{R}, t_{k}^{*}=1$ indicates that $H_{k}$ has the top performance in the whole group. We collect a set of hospitals that possess the top performance in $\boldsymbol{R}$ and denote it as $\boldsymbol{T P}$. Hence, the index set $\boldsymbol{R}$ in model (1) can be substituted by $\boldsymbol{T P}$ (Seiford and Zhu 1998). For hospital $k$ in $\boldsymbol{A}$ is evaluated by (1), $t_{k}^{*}>1$ indicates that $H_{k}$ has the possibility to perform better than $\boldsymbol{R}$ (so as $\boldsymbol{T P}$ ) if weights are set by its optimal solutions; $t_{k}^{*} \leq 1$ indicates that $H_{k}$ could not perform better than all members of $\boldsymbol{R}$ for any given weights. The dual form of model (1) is written as follows:

$$
\begin{array}{ll}
t_{k}^{*}= & \min t_{k} \\
\text { s.t. } & \sum_{j \in \boldsymbol{R}} \lambda_{j} y_{r j} \geq \frac{y_{r k}}{t_{k}}, \quad r=1,2,3 ; \\
& \sum_{j \in \boldsymbol{R}} \lambda_{j}=1 ; \\
& \lambda_{j} \geq 0, \quad j \in \boldsymbol{R} ; t_{k} \geq 0 .
\end{array}
$$

The model could be used to measure the extent of qualification of an accredited hospital $H_{k}$ with respect to group $\boldsymbol{R}$. The classification is based on the following rule:

Rule 1. If $t_{k}^{*}>1$, then $H_{k}$ is qualified. Otherwise $t_{k}^{*} \leq 1, H_{k}$ is unqualified.

In the case where $H_{k}$ is unqualified, the ratio $\left(1 / t_{k}^{*}-1\right)$ is the extent of under-qualification, and this hospital is required to improve the performance of facility, manpower, and disaster plan and drill mode until they reach beyond the levels of $y_{1 k} / t_{k}^{*}, y_{2 k} / t_{k}^{*}$, and $y_{3 k} / t_{k}^{*}$, respectively. In the case where $H_{k}$ is qualified, $\left(1-1 / t_{k}^{*}\right)$ is the ratio of outperformance, and is the maximum extent of deterioration for $H_{k}$ to remain qualified. The deterioration rate indicates how $H_{k}$ is superior to $\boldsymbol{T P}$. The larger value of $t_{k}^{*}$ is, the better the $H_{k}$ does.

However, the optimal value $t_{k}^{*}$ to model (2) reveals the performance of $H_{k}$ with respect to $\boldsymbol{T P}$. For a set of hospitals that is under accredited, one can employ model (2) to assess their relative performances and rank them accordingly. Figure 1 illustrates the relationship between the reference surfaces construct by $\boldsymbol{T P}$ and accredited group $\boldsymbol{A}$ graphically, where the qualified and unqualified classes are separated by the $\boldsymbol{T P}$ surface. It also shows that an unqualified hospital $H_{k}$ requires improvement until it is better than the point $P_{k}$ on the $\boldsymbol{T P}$ surface, where $P_{k}$ is the intersection of the $\boldsymbol{T P}$ surface and the line passing through the origin and $H_{k}$.

\section{Results}

To determine whether a given hospital, $H_{k}$, is qualified or not under accreditation, we employ model (2) to calculate $t_{k}^{*}$ and follow Rule 1 to obtain the classification of $H_{k}$. We used the tool "Solver" embedded in Microsoft Excel to solve model (2). Table 1 presents the following results: 


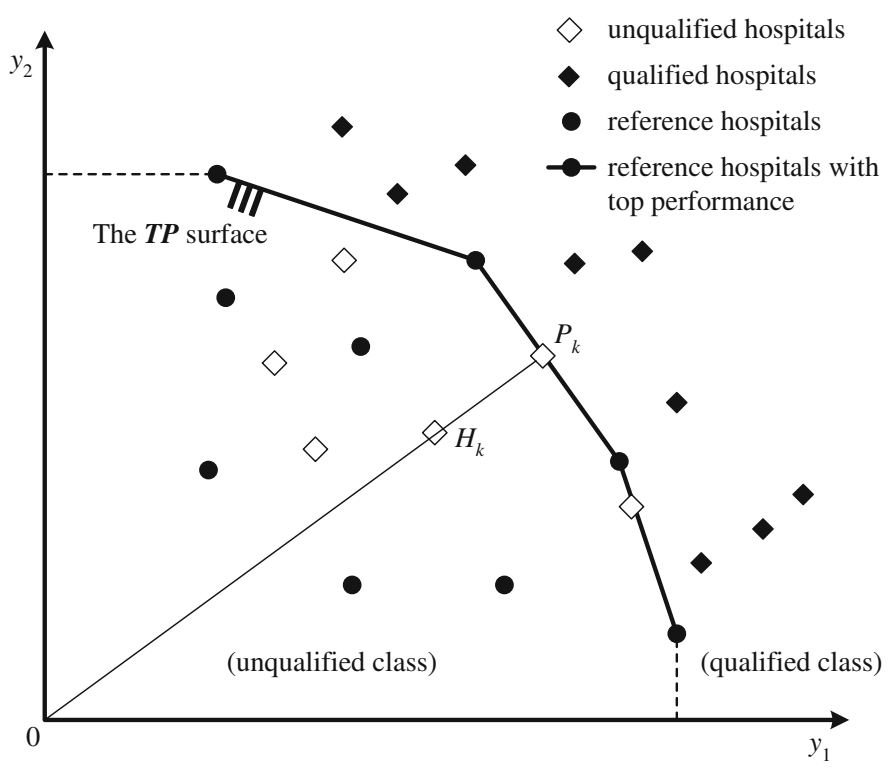

Fig. 1 The reference surface generated by $\boldsymbol{T P}$ and the relationship between qualified and unqualified hospitals in the accredited set

1. The relative performances of the reference hospitals, $H_{1} \sim H_{9}$, are the optimal value to model (2). The performances of $H_{1}, H_{5}, H_{6}$, and $H_{7}$ all equal to one. That is, they performed the best in the whole set $\boldsymbol{R}$. Hence, set $\boldsymbol{T P}$ consists of these four hospitals.

2. Each hospital in $\boldsymbol{A}$ under accreditation was set as $H_{k}$ in model (2) to assess the performance, $t_{k}^{*}$, with respect to $\boldsymbol{R}$. The performances of the 73 accredited hospitals are distributed as: $58(79 \%)$ of them are greater than one, $2(3 \%)$ are equal to one, and 13 $(18 \%)$ are less than one. It means that 58,2 , and 13 of them are superior, even, and inferior to $\boldsymbol{T P}$, respectively. Hence, there are 58 qualified hospitals while the other 15 hospitals are unqualified.

3. The accredited hospitals are ranked appropriately according to their relative performances. For instance, $H_{24}$ with top performance 1.529 is the first rank and $H_{42}$ with the secondary performance 1.49 is the second rank, and so on.

However, an unqualified hospital is required to improve its performance until it becomes qualified. Table 2 depicts the boundary values of the three factors in which the 15 unqualified hospitals should be improved to go beyond. For example, the unqualified $H_{10}$ needs to increase its facility, manpower, and the disaster plan and drill mode factor points beyond the values $40.85,7.54$, and 9.24 , respectively.

We also looked at the performance differences by ownership type and by hospital accredited levels in $\boldsymbol{A}$. These results are presented in Table 3 and 4 . When they are classified by ownership type, there are 25 public hospitals and 48 private hospitals; when they are classified by accredited levels, there are 16 medical centers and 57 regional hospitals. Our findings indicate that on average the private hospitals performed better than the public hospitals, although the differences are not statistically significant by using t, Kruskal-Wallis, and median tests. On average, the medical centers are better than the regional hospitals, although this is not statistically significant. 
Table 2 The target value that the unqualified hospitals should be improved

\begin{tabular}{lllll}
\hline$H_{j}$ & Score $\left(t_{j}^{*}\right)$ & Facility $\left(y_{1 j}\right)$ & Manpower $\left(y_{2 j}\right)$ & Plan \& drill $\left(y_{3 j}\right)$ \\
\hline 10 & 0.822 & $>40.85$ & $>7.54$ & $>9.24$ \\
13 & 1.000 & $>34.80$ & $>10.20$ & $>8.20$ \\
19 & 0.961 & $>34.35$ & $>10.20$ & $>8.12$ \\
25 & 0.815 & $>41.74$ & $>9.08$ & $>7.61$ \\
28 & 1.000 & $>40.80$ & $>10.20$ & $>8.20$ \\
29 & 0.874 & $>40.49$ & $>9.84$ & $>8.69$ \\
30 & 0.998 & $>41.69$ & $>9.22$ & $>8.62$ \\
35 & 0.943 & $>42.00$ & $>4.88$ & $>8.06$ \\
36 & 0.998 & $>41.08$ & $>9.82$ & $>8.62$ \\
41 & 0.786 & $>42.00$ & $>7.89$ & $>8.40$ \\
44 & 0.956 & $>41.64$ & $>9.42$ & $>7.32$ \\
49 & 0.894 & $>32.66$ & $>10.07$ & $>8.72$ \\
60 & 0.957 & $>25.48$ & $>9.40$ & $>9.40$ \\
66 & 0.969 & $>41.92$ & $>8.47$ & $>6.81$ \\
70 & 0.895 & $>42.00$ & $>6.93$ & $>8.94$ \\
\hline
\end{tabular}

Table 3 Efficiency comparison by ownership types

Table 4 Efficiency comparison by accredited levels

\begin{tabular}{llllll}
\hline Ownership type & No. & Mean & SD & Min. & Max. \\
\hline Public & 25 & 1.148 & 0.184 & 0.815 & 1.529 \\
Private & 48 & 1.176 & 0.161 & 0.786 & 1.490 \\
\hline Test & Level & $P$-value & & & \\
\hline$t$-test & 0.690 & 0.494 & & & \\
Kruskal-Wallis & 0.546 & 0.460 & & & \\
Median & 1.082 & 0.298 & & & \\
\hline
\end{tabular}

\begin{tabular}{llllll}
\hline Accredited level & No. & Mean & SD & Min. & Max. \\
\hline Regional & 57 & 1.159 & 0.172 & 0.786 & 1.529 \\
Medical center & 16 & 1.193 & 0.157 & 0.894 & 1.412 \\
\hline Test & Level & $P$-value & & & \\
\hline$t$-test & 0.710 & 0.478 & & & \\
Kruskal-Wallis & 0.729 & 0.393 & & & \\
Median & 1.466 & 0.226 & & & \\
\hline
\end{tabular}




\section{Conclusions and discussions}

In this research, the performance of disaster preparedness planning and temporary shelters in Taiwan's hospitals were measured using three factors. The DEA technique, dealing with non-parametric data, was used in the two-group discriminant problem. The reference set was predetermined by the accreditation committee and their top-practice was regarded as an objective rule of classification. The hospitals under accreditation were expected to be better than the objective. The $\boldsymbol{T P}$ played top in $\boldsymbol{R}$ and constructed a piece-wise linear reference surface to separate the accredited hospitals into qualified and unqualified classes. If a hospital was unqualified, it was recommended to improve its practice until it moved beyond $\boldsymbol{T P}$.

This research did not focus on discriminating efficient hospitals from inefficient ones. We proposed the reference boundary of passing the evaluation and suggested that all hospitals needed to reach beyond the boundary. The DEA classification technique is important for decision-making problems where decision makers are interested in knowing the changes in attributes for moving an unqualified unit into the qualified class. In this application, the classification method promotes the quality of disaster preparedness planning and temporary shelters, indicates which hospital does not satisfy our requirements, and provides what the hospital needs to improve in order to achieve the qualification level.

In this research, the reference boundary is not assigned prior to the accreditation. We just selected some hospitals based on minor emergency patients as the least needed for this accreditation. Then, a detached classification boundary was relatively determined by the top practice of these hospitals. This analysis is not consistent with other discriminant analysis. It used only the data with one group to develop a boundary, instead of data with two or more groups. This non-parametric DEA classification can be widely applied in future accreditation or risk management problems.

The limitation of this study is the selection of the reference set. The setting of the threshold value as the reference set $\boldsymbol{R}$ may affect the accreditation results. What is the suitable percentage of hospitals that should be set to $\boldsymbol{R}$ ? or, what would happen if the reference hospitals had performed better? Setting a higher value, or including a better hospital in the reference, would result in more hospitals needing to improve their disaster preparedness capability. Setting a lower value would result in less hospitals needing to be improved. In this study, the committee subjectively selected nine reference hospitals based on the assumptions and their experience. However, a region under higher threat from disasters may set a larger value to have a higher preparedness capability, or one may set a value in a gradually increasing manner if the accreditation process is held periodically.

In the long run, some regional hospitals could be selected as a reference set. It is expected that a medical center under accreditation should operate superior to the reference set, otherwise it should improve its performance beyond the boundary. In the risk management problem, organizations that do not operate well or are even bankrupt could be identified in advance, then the top performance of these pre-selected organizations could be assessed as the reference. It requires that all of the current organizations perform better than the boundary value as risk prevented units. While the organizations are not better than the boundary, the organizations have a high risk of going bankrupt, and must improve they go beyond the boundary.

Acknowledgements This research was partly supported by the Department of Health, Executive Yuan of Taiwan, DOH90-TD-1064. 


\section{Appendix}

Measurement chart and measurement guides

\section{Part 1. Fixed structure}

Proportion of scores: 65 points

\begin{tabular}{|c|c|c|c|c|c|}
\hline \multirow{2}{*}{$\begin{array}{c}\text { Subtotal } \\
\text { Ranks }\end{array}$} & \multicolumn{5}{|c|}{ __ points } \\
\hline & Excellent & Good & Adequate & $\begin{array}{c}\text { Mild } \\
\text { deficiency }\end{array}$ & Deficiency \\
\hline Weights & 1.0 & 0.8 & 0.6 & 0.4 & 0.2 \\
\hline $\begin{array}{l}\text { Space ownership ( } 3 \text { points) } \\
\text { 1. } \square \text { private land, oral appointment } \\
\text { 2. } \square \text { rental } \\
\text { 3. } \square \text { hospital property } \\
\text { 4. } \square \text { others }\end{array}$ & \multicolumn{5}{|c|}{$\begin{array}{l}\text { Excellent: with characteristic of feasibility, stability, } \\
\text { flexibility, and safety. } \\
\text { Good: with } 3 \text { of above characteristics. } \\
\text { Adequate: with } 2 \text { of above characteristics. } \\
\text { Mild deficiency: with } 1 \text { of above characteristic. } \\
\text { Deficiency: none. }\end{array}$} \\
\hline $\begin{array}{l}\text { Space type (5 points) } \\
\text { 1. } \square \text { building } \\
\text { 2. } \square \text { underground building } \\
\text { 3. } \square \text { open-ended space } \\
\text { 4. } \square \text { others }\end{array}$ & \multicolumn{5}{|c|}{ Same as above. } \\
\hline $\begin{array}{l}\text { Space area (4 points) } \\
\text { 1. } \square<200 \mathrm{~m}^{2} \\
\text { 2. } \square 200-500 \mathrm{~m}^{2} \\
\text { 3. } \square 500-1000 \mathrm{~m}^{2} \\
\text { 4. } \square>1000 \mathrm{~m}^{2} \\
\text { 5. } \square \text { others }\end{array}$ & \multicolumn{5}{|c|}{ Same as above. } \\
\hline $\begin{array}{l}\text { Space site ( } 2 \text { points) } \\
\text { 1. } \square \text { private land, oral appointment } \\
\text { 2. } \square \text { rental } \\
\text { 3. } \square \text { hospital property } \\
\text { 4. } \square \text { others }\end{array}$ & \multicolumn{5}{|c|}{ Same as above. } \\
\hline $\begin{array}{l}\text { Space capacity ( } 4 \text { points) } \\
\text { 1. } \square<50 \text { people } \\
\text { 2. } \square \text { 50-100 people } \\
\text { 3. } \square 100-200 \text { people } \\
\text { 4. } \square>200 \text { people } \\
\text { 5. } \square \text { others }\end{array}$ & \multicolumn{5}{|c|}{ Same as above. } \\
\hline $\begin{array}{l}\text { Space design ( } 7 \text { points) } \\
\text { 1. } \square \text { clear sign for day and night } \\
\text { 2. } \square \text { control gate } \\
\text { 3. } \square \text { easy entrance and exit } \\
\text { 4. } \square \text { more than } 2 \text { exits } \\
\text { 5. } \square \text { good ventilation } \\
\text { 6. } \square \text { examination/operation room } \\
\text { 7. } \square \text { space for drug \& supplies storage } \\
\text { 8. } \square \text { isolated room and space } \\
\text { 9. } \square \text { others }\end{array}$ & \multicolumn{5}{|c|}{$\begin{array}{l}\text { Excellent: with }>5 \text { of left items. } \\
\text { Good: with } 5 \text { of left items. } \\
\text { Adequate: with } 4 \text { of left items. } \\
\text { Mild deficiency: with } 3 \text { of left items. } \\
\text { Deficiency: with }<3 \text { of left items. }\end{array}$} \\
\hline
\end{tabular}


Part 1. Fixed structure (continue 1)

\begin{tabular}{|c|c|c|c|c|c|}
\hline Ranks & Excellent & Good & Adequate & $\begin{array}{c}\text { Mild } \\
\text { deficiency }\end{array}$ & Deficiency \\
\hline Weights & 1.0 & 0.8 & 0.6 & 0.4 & 0.2 \\
\hline $\begin{array}{l}\text { Emergence power supply ( } 4 \text { points) } \\
\text { 1. } \square \text { small generator } \\
\text { 2. } \square \text { big generator } \\
\text { 3. } \square \text { un-disconnect system } \\
\text { 4. } \square \text { others }\end{array}$ & \multicolumn{5}{|c|}{$\begin{array}{l}\text { Excellent: with characteristic of feasibility, stability, } \\
\text { flexibility, and safety. } \\
\text { Good: with } 3 \text { of above characteristics. } \\
\text { Adequate: with } 2 \text { of above characteristics. } \\
\text { Mild deficiency: with } 1 \text { of above characteristic. } \\
\text { Deficiency: none. }\end{array}$} \\
\hline $\begin{array}{l}\text { Ventilation facility ( } 3 \text { points) } \\
\text { 1. } \square \text { fan } \\
\text { 2. } \square \text { exhaust fan } \\
\text { 3. } \square \text { air-conditioner } \\
\text { 4. } \square \text { central air-conditioner } \\
\text { 5. } \square \text { others }\end{array}$ & \multicolumn{5}{|c|}{ Same as above. } \\
\hline $\begin{array}{l}\text { Water supply ( } 3 \text { points) } \\
\text { 1. } \square \text { warm drinking water } \\
\text { 2. } \square \text { drinking fountain } \\
\text { 3. } \square \text { central warm water } \\
\text { 4. } \square \text { U-V antiseptic } \\
\text { 5. } \square \text { retrograde system } \\
\text { 6. } \square \text { others }\end{array}$ & \multicolumn{5}{|c|}{ Same as above. } \\
\hline $\begin{array}{l}\text { Communication facilities (4 points) } \\
\text { 1. } \square \text { telephone } \\
\text { 2. } \square \text { cell phone } \\
\text { 3. } \square \text { fax machine } \\
\text { 4. } \square \text { walky-talky } \\
\text { 5. } \square \text { broadcast system } \\
\text { 6. } \square \text { satellite phone } \\
\text { 7. } \square \text { computer line } \\
\text { 8. } \square \text { others }\end{array}$ & \multicolumn{5}{|c|}{ Same as above. } \\
\hline $\begin{array}{l}\text { Oxygen supply ( } 3 \text { points) } \\
\text { 1. } \square \text { small container } \\
\text { 2. } \square \text { big container } \\
\text { 3. } \square \text { pre-set central tube } \\
\text { 4. } \square \text { pre-set single tube } \\
\text { 5. } \square \text { others }\end{array}$ & \multicolumn{5}{|c|}{ Same as above. } \\
\hline $\begin{array}{l}\text { Transportation ( } 2 \text { points) } \\
\text { 1. } \square \text { small bus } \\
\text { 2. } \square \text { big bus } \\
\text { 3. } \square \text { ambulance } \\
\text { 4. } \square \text { others }\end{array}$ & \multicolumn{5}{|c|}{ Same as above. } \\
\hline
\end{tabular}


Part 1. Fixed structure (continue 2)

\begin{tabular}{|c|c|c|c|c|c|}
\hline Ranks & Excellent & Good & Adequate & $\begin{array}{c}\text { Mild } \\
\text { deficiency }\end{array}$ & Deficiency \\
\hline Weights & 1.0 & 0.8 & 0.6 & 0.4 & 0.2 \\
\hline $\begin{array}{l}\text { Emergence equipments (6 points) } \\
\text { 1. } \square \text { defibrillator } \\
\text { 2. } \square \text { vital sign monitor } \\
\text { 3. } \square \text { rescue package } \\
\text { 4. } \square \text { ventilator } \\
\text { 5. } \square \text { EKG monitor } \\
\text { 6. } \square \text { X-ray machine } \\
\text { 7. } \square \text { blood lab } \\
\text { 8. } \square \text { suction } \\
\text { 9. } \square \text { operation room } \\
\text { 10. } \square \text { stretcher/wheel chair/ER bed } \\
\text { 11. } \square \text { others }\end{array}$ & \multicolumn{5}{|c|}{$\begin{array}{l}\text { Excellent: with }>8 \text { of left items. } \\
\text { Good: with } 7-8 \text { of left items. } \\
\text { Adequate: with 5-6 of left items. } \\
\text { Mild deficiency: with 3-4 of left items. } \\
\text { Deficiency: with }<3 \text { of left items. }\end{array}$} \\
\hline $\begin{array}{l}\text { Eating space ( } 3 \text { points) } \\
\text { 1. } \square \text { indoor } \\
\text { 2. } \square \text { outdoor } \\
\text { 3. } \square \text { whole day supply } \\
\text { 4. } \square \text { fire safety } \\
\text { 5. } \square \text { others }\end{array}$ & \multicolumn{5}{|c|}{$\begin{array}{l}\text { Excellent: with characteristic of feasibility, stability, } \\
\text { flexibility, and safety. } \\
\text { Good: with } 3 \text { of above characteristics. } \\
\text { Adequate: with } 2 \text { of above characteristics. } \\
\text { Mild deficiency: with } 1 \text { of above characteristic. } \\
\text { Deficiency: none. }\end{array}$} \\
\hline $\begin{array}{l}\text { Dressing \& sleeping supply (4 points) } \\
\text { 1. } \square \text { clothes } \\
\text { 2. } \square \text { blanket } \\
\text { 3. } \square \text { mosquito net } \\
\text { 4. } \square \text { sleeping bag } \\
\text { 5. } \square \text { tent } \\
\text { 6. } \square \text { others }\end{array}$ & \multicolumn{5}{|c|}{ Same as above. } \\
\hline $\begin{array}{l}\text { Toilet (3 points) } \\
\text { 1. } \square \text { fix toilet } \\
\text { 2. } \square \text { movable toilet } \\
\text { 3. } \square \text { privacy } \\
\text { 4. } \square \text { hand wash } \\
\text { 5. } \square \text { tissue paper } \\
\text { 6. } \square \text { others }\end{array}$ & \multicolumn{5}{|c|}{ Same as above. } \\
\hline $\begin{array}{l}\text { Bathroom ( } 2 \text { points) } \\
\text { 1. } \square \text { privacy } \\
\text { 2. } \square \text { hot water } \\
\text { 3. } \square \text { shower } \\
\text { 4. } \square \text { others }\end{array}$ & \multicolumn{5}{|c|}{ Same as above. } \\
\hline $\begin{array}{l}\text { Kitchen ( } 3 \text { points) } \\
\text { 1. } \square \text { indoor } \\
\text { 2. } \square \text { outdoor } \\
\text { 3. } \square \text { water supply } \\
\text { 4. } \square \text { residual food management } \\
\text { 5. } \square \text { fire safety } \\
\text { 6. } \square \text { others }\end{array}$ & \multicolumn{5}{|c|}{ Same as above. } \\
\hline
\end{tabular}


Part 2. Manpower

Proportion of scores: 20 points

\begin{tabular}{|c|c|c|c|c|c|}
\hline \multirow{2}{*}{$\begin{array}{c}\text { Subtotal } \\
\text { Ranks }\end{array}$} & \multicolumn{5}{|c|}{$\ldots$ points } \\
\hline & Excellent & Good & Adequate & $\begin{array}{c}\text { Mild } \\
\text { deficiency }\end{array}$ & Deficiency \\
\hline Weights & 1.0 & 0.8 & 0.6 & 0.4 & 0.2 \\
\hline $\begin{array}{l}\text { ER doctor (4 points) } \\
\text { 1. } \square \text { specific arranged } \\
\text { 2. } \square \text { at least internist \& surgeon } \\
\text { 3. } \square \text { at least leaded by senior resident } \\
\text { 4. } \square \text { standard process protocol } \\
\text { 5. } \square \text { at least } 2 \text { group for shift } \\
\text { 6. } \square \text { others }\end{array}$ & \multicolumn{5}{|c|}{$\begin{array}{l}\text { Excellent: with }>4 \text { of left items. } \\
\text { Good: with } 4 \text { of left items. } \\
\text { Adequate: with } 3 \text { of left items. } \\
\text { Mild deficiency: with } 2 \text { of left items. } \\
\text { Deficiency: with } 1 \text { or none of left items. }\end{array}$} \\
\hline $\begin{array}{l}\text { ER nurse ( } 3 \text { points) } \\
\text { 1. } \square \text { specific arranged } \\
\text { 2. } \square \text { ER cares training (eg. ACLS) } \\
\text { 3. } \square \text { standard process protocol } \\
\text { 4. } \square \text { at least } 2 \text { group for shift } \\
\text { 5. } \square \text { others }\end{array}$ & \multicolumn{5}{|c|}{$\begin{array}{l}\text { Excellent: with }>3 \text { of left items. } \\
\text { Good: with } 3 \text { of left items. } \\
\text { Adequate: with } 2 \text { of left items. } \\
\text { Mild deficiency: with } 1 \text { of left items. } \\
\text { Deficiency: none. }\end{array}$} \\
\hline $\begin{array}{l}\text { ER volunteer ( } 1 \text { point) } \\
\text { 1. } \square \text { specific arranged } \\
\text { 2. } \square \text { first aid training } \\
\text { 3. } \square \text { know the standard procedure } \\
\text { 4. } \square \text { good communication ability } \\
\text { 5. } \square \text { at least } 2 \text { group for shift } \\
\text { 6. } \square \text { others }\end{array}$ & \multicolumn{5}{|c|}{$\begin{array}{l}\text { Excellent: with }>4 \text { of left items. } \\
\text { Good: with } 4 \text { of left items. } \\
\text { Adequate: with } 3 \text { of left items. } \\
\text { Mild deficiency: with } 2 \text { of left items. } \\
\text { Deficiency: with } 1 \text { or none of left items. }\end{array}$} \\
\hline $\begin{array}{l}\text { Food provider ( } 2 \text { points) } \\
\text { 1. } \square \text { specific arranged } \\
\text { 2. } \square \text { with license } \\
\text { 3. } \square \text { first aid training } \\
\text { 4. } \square \text { know of standard procedure } \\
\text { 5. } \square \text { at least } 2 \text { group for shift } \\
\text { 6. } \square \text { others }\end{array}$ & \multicolumn{5}{|c|}{ Same as above. } \\
\hline $\begin{array}{l}\text { Transportation staff ( } 2 \text { points) } \\
\text { 1. } \square \text { specific arranged } \\
\text { 2. } \square \text { with license } \\
\text { 3. } \square \text { EMT-1 training } \\
\text { 4. } \square \text { know of standard procedure } \\
\text { 5. } \square \text { at least } 2 \text { group for shift } \\
\text { 6. } \square \text { others }\end{array}$ & \multicolumn{5}{|c|}{ Same as above. } \\
\hline $\begin{array}{l}\text { Maintenance staff ( } 2 \text { points) } \\
\text { 1. } \square \text { specific arranged } \\
\text { 2. } \square \text { with license } \\
\text { 3. } \square \text { first aid training } \\
\text { 4. } \square \text { know of standard procedure } \\
\text { 5. } \square \text { at least } 2 \text { group for shift } \\
\text { 6. } \square \text { others }\end{array}$ & \multicolumn{5}{|c|}{ Same as above. } \\
\hline
\end{tabular}


Part 2. Manpower (continue)

\begin{tabular}{|c|c|c|c|c|c|}
\hline Ranks & Excellent & Good & Adequate & $\begin{array}{c}\text { Mild } \\
\text { deficiency }\end{array}$ & Deficiency \\
\hline Weights & 1.0 & 0.8 & 0.6 & 0.4 & 0.2 \\
\hline $\begin{array}{l}\text { Social worker ( } 2 \text { points) } \\
\text { 1. } \square \text { specific arranged } \\
\text { 2. } \square \text { first aid training } \\
\text { 3. } \square \text { good communication ability } \\
\text { 4. } \square \text { have standard procedure } \\
\text { 5. } \square \text { at least } 2 \text { group for shift } \\
\text { 6. } \square \text { others }\end{array}$ & \multicolumn{5}{|c|}{$\begin{array}{l}\text { Excellent: with }>4 \text { of left items. } \\
\text { Good: with } 4 \text { of left items. } \\
\text { Adequate: with } 3 \text { of left items. } \\
\text { Mild deficiency: with } 2 \text { of left items. } \\
\text { Deficiency: with } 1 \text { or none of left items. }\end{array}$} \\
\hline $\begin{array}{l}\text { Housekeeping staff ( } 2 \text { points) } \\
\text { 1. } \square \text { specific arranged } \\
\text { 2. } \square \text { first aid training } \\
\text { 3. } \square \text { good communication ability } \\
\text { 4. } \square \text { know of standard procedure } \\
\text { 5. } \square \text { at least } 2 \text { group for shift } \\
\text { 6. } \square \text { others }\end{array}$ & \multicolumn{5}{|c|}{ Same as above. } \\
\hline $\begin{array}{l}\text { Administrative staff ( } 2 \text { points) } \\
\text { 1. } \square \text { specific arranged } \\
\text { 2. } \square \text { first aid training } \\
\text { 3. } \square \text { good communication ability } \\
\text { 4. } \square \text { know of standard procedure } \\
\text { 5. } \square \text { at least } 2 \text { group for shift } \\
\text { 6. } \square \text { others }\end{array}$ & \multicolumn{5}{|c|}{ Same as above. } \\
\hline
\end{tabular}

Part 3. Disaster planning and dril mode

\begin{tabular}{|c|c|c|c|c|c|}
\hline \multicolumn{4}{|c|}{ Proportion of scores: 15 points } & & \\
\hline \multirow{2}{*}{$\begin{array}{c}\text { Subtotal } \\
\text { Ranks }\end{array}$} & \multicolumn{5}{|c|}{$\ldots$ points } \\
\hline & Excellent & Good & Adequate & $\begin{array}{c}\text { Mild } \\
\text { deficiency }\end{array}$ & Deficiency \\
\hline Weights & 1.0 & 0.8 & 0.6 & 0.4 & 0.2 \\
\hline $\begin{array}{l}\text { Disaster written plan ( } 5 \text { points) } \\
\text { 1. } \square \text { have written plan } \\
\text { 2. } \square \text { have improvement process } \\
\text { 3. } \square \text { scheduled meeting } \\
\text { 4. } \square \text { have activation guide } \\
\text { 5. } \square \text { others }\end{array}$ & \multicolumn{5}{|c|}{$\begin{array}{l}\text { Excellent: with characteristic of feasibility, stability, } \\
\text { flexibility, and safety. } \\
\text { Good: with } 3 \text { of above characteristics. } \\
\text { Adequate: with } 2 \text { of above characteristics. } \\
\text { Mild deficiency: with } 1 \text { of above characteristic. } \\
\text { Deficiency: none. }\end{array}$} \\
\hline
\end{tabular}


Part 3. Disaster planning and dril mode (continue)

\begin{tabular}{|c|c|c|c|c|c|}
\hline Ranks & Excellent & Good & Adequate & $\begin{array}{c}\text { Mild } \\
\text { deficiency }\end{array}$ & Deficiency \\
\hline Weights & 1.0 & 0.8 & 0.6 & 0.4 & 0.2 \\
\hline $\begin{array}{l}\text { Disaster drill plan ( } 2 \text { points) } \\
\text { 1. } \square \text { carry out biannually } \\
\text { 2. } \square \text { carry out annually } \\
\text { 3. } \square \text { carry out irregularly } \\
\text { 4. } \square \text { biannually, not carry out } \\
\text { 5. } \square \text { annually, not carry out } \\
\text { 6. } \square \text { others }\end{array}$ & \multicolumn{5}{|c|}{$\begin{array}{l}\text { Excellent: with item } 1 \text { of left. } \\
\text { Good: with item } 2 \text { of left. } \\
\text { Adequate: with item } 3 \text { of left. } \\
\text { Mild deficiency: with item } 4 \text { or } 5 \text { of left. } \\
\text { Deficiency: none. }\end{array}$} \\
\hline $\begin{array}{l}\text { Drill mode ( } 2 \text { points) } \\
\text { 1. } \square \text { one hospital only } \\
\text { 2. } \square \text { with other nearby organizations } \\
\text { 3. } \square \text { both } \\
\text { 4. } \square \text { others }\end{array}$ & \multicolumn{5}{|c|}{$\begin{array}{l}\text { Excellent: with characteristic of feasibility, stability, } \\
\text { flexibility, and safety. } \\
\text { Good: with } 3 \text { of above characteristics. } \\
\text { Adequate: with } 2 \text { of above characteristics. } \\
\text { Mild deficiency: with } 1 \text { of above characteristic. } \\
\text { Deficiency: none. }\end{array}$} \\
\hline $\begin{array}{l}\text { Improvement meeting plan ( } 2 \text { points) } \\
\text { 1. } \square \text { carry out biannually } \\
\text { 2. } \square \text { carry out annually } \\
\text { 3. } \square \text { carry out irregularly } \\
\text { 4. } \square \text { biannually, not carry out } \\
\text { 5. } \square \text { annually, not carry out } \\
\text { 6. } \square \text { others }\end{array}$ & \multicolumn{5}{|c|}{$\begin{array}{l}\text { Excellent: with item } 1 \text { of left. } \\
\text { Good: with item } 2 \text { of left. } \\
\text { Adequate: with item } 3 \text { of left. } \\
\text { Mild deficiency: with item } 4 \text { or } 5 \text { of left. } \\
\text { Deficiency: none. }\end{array}$} \\
\hline $\begin{array}{l}\text { Response time ( } 2 \text { points) } \\
\text { 1. } \square \text { within one hour } \\
\text { 2. } \square \text { within } 1-3 \text { hours } \\
\text { 3. } \square \text { within } 3-6 \text { hours } \\
\text { 4. } \square \text { within } 6-12 \text { hours } \\
\text { 5. } \square \text { more than } 12 \text { hours } \\
\text { 6. } \square \text { others }\end{array}$ & \multicolumn{5}{|c|}{$\begin{array}{l}\text { Excellent: with item } 1 \text { of left. } \\
\text { Good: with item } 2 \text { of left. } \\
\text { Adequate: with item } 3 \text { of left. } \\
\text { Mild deficiency: with item } 4 \text { of left. } \\
\text { Deficiency: with none or item } 5 \text { of left. }\end{array}$} \\
\hline $\begin{array}{l}\text { Capability in } 2 \text { hours ( } 2 \text { points) } \\
\text { 1. } \square<25 \text { patients } \\
\text { 2. } \square 25-50 \text { patients } \\
\text { 3. } \square 51-100 \text { patients } \\
\text { 4. } \square 101-200 \text { patients } \\
\text { 5. } \square>200 \text { patients } \\
\text { 6. } \square \text { others }\end{array}$ & \multicolumn{5}{|c|}{$\begin{array}{l}\text { Excellent: with item } 5 \text { of left. } \\
\text { Good: with item } 4 \text { of left. } \\
\text { Adequate: with item } 3 \text { of left. } \\
\text { Mild deficiency: with item } 2 \text { of left. } \\
\text { Deficiency: with none or item } 1 \text { of left. }\end{array}$} \\
\hline
\end{tabular}

\section{References}

Aghababian, R.V., Lewis, C.P., Gans, L.: Disaster within hospitals. Ann. Emerg. Med. 23(4), 771-777 (1994) Burgess, J.F., Wilson, P.W.: Hospital ownership and technical inefficiency. Manag. Sci. 42(1), 110-123 (1996) Burgess, J.F., Wilson, P.W.: Variation in inefficiency among US hospitals. INFOR 36(3), 84-102 (1998)

Charnes, A., Cooper, W.W., Rhodes, E.: Measuring the efficiency of decision making units. Eur. J. Oper. Res. 2, 429-444 (1978)

Chen, W.K., Cheng, Y.C., Ng, K.C., Hung, J.J., Chuang, C.M.: Were there enough physicians in an emergency department in the affected area after a major earthquake? An analysis of the Taiwan Chi-Chi earthquake in 1999. Ann. Emerg. Med. 38(5), 556-561 (2001) 
Department of Health. The Rules of Massive Patient Emergency Care in Emergency Medical Service. Department of Health, Executive Yuan, Taiwan. http://dohlaw.doh.gov.tw/Chi/FLAW/FLAWDAT0202. asp (2000). Accessed 15 May 2008 (in Chinese)

Department of Health. Emergency Medical Service Act. Department of Health, Executive Yuan, Taiwan. http:// www.doh.gov.tw/ufile/doc/Emergency\%20Medical\%20Services\%20Act.pdf (2007). Accessed 15 May 2008

Grosskopf, S., Margaritis, D., Valdmanis, V.: Comparing teaching and non-teaching hospitals: a frontier approach (teaching vs. non-teaching hospitals). Health Care Manag. Sci. 4(2), 83-90 (2001)

Heide, E.A.: Community Medical Planning and Evaluation Guide. America College Emergency Physician, Texas (1995)

Hofmarcher, M.M., Paterson, I., Riedel, M.: Measuring hospital efficiency in Austria —a DEA approach. Health Care Manag. Sci. 5(1), 7-14 (2002)

Joint Commission on Accreditation of Healthcare Organizations (JCAHO). 1994 Accreditation Manual for Hospital, II, pp. 14-18. JCAHO, Oakbrook Terrance (1994)

NFPA. NFPA 1600: Standard on Disaster/Emergency Management and Business Continuity Programs. http:// www.nfpa.org/assets/files/PDF/NFPA1600.pdf (2007). Accessed 15 May 2008

Pretto, E.A., Ricci, E., Klain, M.: Disaster reanimatology potentials: a structured interview study in America. III. Results, conclusions and recommendations. Prehosp. Disaster Med. 7, 327-337 (1992)

Pretto, E.A., Angus, D.C., Abrams, J.I.: An analysis of prehospital mortality in an earthquake. Disaster Reanimatology Study Group. Prehosp. Disaster Med. 9(2), 107-117 (1994)

Safar, P.: Rescuscitation potentials in mass disasters. Prehosp. Disaster Med. 2, 34-47 (1986)

Seiford, L.M., Zhu, J.: An acceptance system decision rule with data envelopment analysis. Comput. Oper. Res. 25(4), 329-332 (1998)

Sphere Project. Sphere Handbook: Humanitarian Charter and Minimum Standards in Disaster Response, 2nd edn. Oxfam Publishing, Oxford (2004)

Taiwan Joint Commission on Hospital Accreditation. Hospital Accreditation and Evaluation Table. http:// www.tjcha.org.tw/NewsDetail.asp?NewsId=317 (1999). Accessed 15 May 2008 (in Chinese)

The Joint Australian/New Zealand Standard. AS/NZS 4360: 2004, Risk Management. SAI Global, Sydney (2004) 